\author{
R.E. Khoma ${ }^{a, b}$, V.N. Baumer ${ }^{c}$, P.B. Antonenko ${ }^{d}$, A.O. Snihach ${ }^{d}$, V.V. Godovan ${ }^{d}$, \\ A.A. Ennan ${ }^{a}$, R.M. Dlubovskii ${ }^{a}$, V.O. Gelmboldt ${ }^{d}$
}

\title{
SYNTHESIS, CRYSTAL STRUCTURE, AND SPECTRAL CHARACTERISTICS OF N-( $N$-PROPYL)AMINOMETHANESULFONIC ACID. ACUTE TOXICITY OF AMINOMETHANESULFONIC ACID AND ITS N-ALKYLATED DERIVATIVES
}

\author{
a Physical-Chemical Institute for Environment and Human Protection of MES of Ukraine and NAS of \\ Ukraine, Odessa, Ukraine

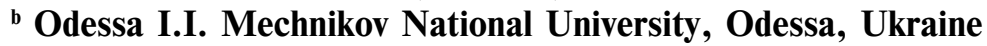 \\ ${ }^{c}$ Institute for Single Crystals of the NAS of Ukraine, Kharkiv, Ukraine \\ d Odessa National Medical University, Odessa, Ukraine
}

\begin{abstract}
Aminomethanesulfonic acid (Ia), and its N-methyl (IIa), N-n-propyl (IIIa), N-tert-butyl (IVa) derivatives were synthesized (IIIa has not been previously described) and characterized by means of X-ray diffraction analysis, IR spectroscopy, and mass spectrometry. Aminosulfonic acid $3 \mathrm{a}$ of zwitterionic structure crystallizes in the orthorhombic space group Iba2 with the following cell parameters: $a=8.8405(6) \AA, b=20.6348(12) \AA, c=8.0433(7) \AA$, $\alpha=\beta=\gamma=90^{\circ}, V=1467.27(18) \AA^{3}$. The aqueous solutions of sodium salts $(\mathrm{Ib}-\mathrm{IVb})$ were prepared by reacting $\mathrm{NaOH}$ with the corresponding Ia-IVa acids in equimolar amounts. The toxicity of $\mathrm{Ib}-\mathrm{IVb}$ was studied on 132 mice. The derivatives of aminomethanesulfonic acid belong to almost non-toxic compounds ( $\mathrm{V}$ category of toxicity) following both intraperitoneal and oral administration in mice. According to the $\mathrm{LD}_{50}$ values, the compounds could be ranked in the following order: IIIb $(2110 \mathrm{mg} / \mathrm{kg})<\mathrm{IIb}(2925 \mathrm{mg} / \mathrm{kg})<\mathrm{IVb}(3020$ $\mathrm{mg} / \mathrm{kg})<\mathrm{Ib}(3470 \mathrm{mg} / \mathrm{kg})$. Aminomethanesulfonic acid derivatives may be safely used in buffer solution as well as for further investigation as potential medicine agents.
\end{abstract}

Keywords: aminomethanesulfonic acids, synthesis, crystal structure, spectral characteristics, acute toxicity.

DOI: $10.32434 / 0321-4095-2019-127-6-255-262$

\section{Introduction}

The derivatives of aminoalkanosulfonic acids, in particular salts of aminomethanesulfonic acid (AMSA), have found widespread use in buffer solutions to maintain the $\mathrm{pH}$ of the medium to control the rate and efficiency of biological processes $[1,2]$. In biological studies, the use of AMSA is preferable to other classes of buffer compounds (citrates, borates, etc.) that are characterized by unacceptable toxicity or undesirable metabolic effects. AMSA and its derivatives also have cytostatic, antiviral, antimicrobial, and anti-atherogenic activity $[1,3,4]$. The non-narcotic analgesic metamisole (analgin) is a derivative of AMSA. The structure of 2 -aminomethanesulfonic acid (taurine) is close to that of the aminomethanesulfonic acid. According to literature data, taurine regulates translocation of mitochondrial proteins, has antioxidant and neuroprotective activity and activates GABAA and glycine receptors in the Central Nervous System (CNS) [5].

Earlier, we proposed a new one-stage synthesis of AMSA with a high yield of the targeted product (up to 95\%) and easy availability of the original substances [6]. Only AMSA, and its N-methyl [7], N-(2-hydroxyethyl) [8], N-tert-butyl [9] derivatives were characterized structurally. AMSA and its Nalkylated derivatives demonstrated antiviral activity against the influenza virus strain A/PR/8/34 (H1N1) and A/Hong Kong/1/68 (H3N2) in chorio-allantoic covers of 10-12-days chicken embryos tissue culture [3].

On the basis of results $[6,8,9]$, we attempted to prepare AMSA and three of its $\mathrm{N}$-derivatives with the use of methylamine, $n$-propylame, tertbutylamine. In present work, we describe the

(c) R.E. Khoma, V.N. Baumer, P.B. Antonenko, A.O. Snihach, V.V. Godovan, A.A. Ennan, R.M. Dlubovskii,

V.O. Gelmboldt, 2019

Synthesis, crystal structure, and spectral characteristics of $N$-(n-propyl)aminomethanesulfonic acid. Acute toxicity of aminomethanesulfonic acid and its $N$-alkylated derivatives 
synthesis of $\mathrm{N}$-( $n$-propyl)aminomethanesulfonic acid and the study of its structure. In addition, we examine the toxicometric characteristics of aminomethanesulfonic acids in experiment via different routes of administration.

\section{Experimental}

\section{Synthesis}

Aminomethanesulfonic acid (Ia) was prepared using the procedure similar to that described elsewhere [6]. Mass spectrum EI: $\left[\mathrm{SO}_{2}\right]^{+} \cdot(\mathrm{m} / \mathrm{z} 64, \mathrm{I}$, $100 \%),[\mathrm{SO}]^{+}$(m/z 48, I, 31\%), m/z 42, I, $15 \%$.

\section{$\mathrm{N}$-Methylaminomethanesulfonic acid (IIa)}

Equimolar amount of paraformaldehyde was added to the solution of methyamine $(0.10 \mathrm{~mol})$ in $25 \mathrm{~mL}$ of water at cooling $\left(\mathrm{t} \leq 10^{\circ} \mathrm{C}\right)$ and the reaction mixture was left standing for $24 \mathrm{~h}$. Then, $\mathrm{SO}_{2}$ was bubbled through the resulting solution to $\mathrm{pH} \leq 1.0$ followed by keeping the reaction mixture at room temperature to achieve complete evaporation of water. Yield $12.32 \mathrm{~g}(\sim 100 \%)$, white crystals, $\mathrm{mp}$. $167-168^{\circ} \mathrm{C}$ (decomp.). IR spectrum, $v, \mathrm{~cm}^{-1}: 3172$ (NH); 3060, 3027, 2973, 2896, $2818(\mathrm{NH}, \mathrm{CH})$; $2574,2511,2447,2389\left(\left[\mathrm{NH}_{2}\right]^{+}\right) ; 1617,1581$ $\left[\delta\left(\mathrm{N}^{+} \mathrm{H}_{2}\right)\right] ; 1240,1183\left(\mathrm{SO}_{2}\right) ; 1085,1053,1029\left(\mathrm{SO}_{2}\right)$; $541(\mathrm{~S}-\mathrm{O})$. Mass spectrum FAB: $[\mathrm{M}+\mathrm{H}]^{+}(\mathrm{m} / \mathrm{z} 126$, $\mathrm{I}, 8 \%),[\mathrm{M}-\mathrm{H}]^{+}(\mathrm{m} / \mathrm{z} 124, \mathrm{I}, 5 \%),\left[\mathrm{M}-\mathrm{SO}_{3}-2 \mathrm{H}\right]^{+}$ (m/z 43, I, 9\%). Anal. calcd. $\mathrm{C}_{2} \mathrm{H}_{7} \mathrm{NO}_{3} \mathrm{~S}$ : C 23.22; H 5.85; N 9.03; S 20.66. Found: C 19.67; H 5.27; N 10.84; S 25.93. M 155.15.

$\mathrm{N}$-(n-Propyl)aminomethanesulfonic acid (IIIa)

Paraformaldehyde was added in an equimolar ratio to the solution of $0.10 \mathrm{~mol}$ of $\mathrm{n}$-propylamine in $40 \mathrm{~mL}$ of water, cooled to $\leq 10^{\circ} \mathrm{C}$ and kept for $24 \mathrm{~h}$. Then, $\mathrm{SO}_{2}$ was bubbled through the formed heterogenic mixture (oil-like cloudy white liquid over aqueous solution) till $\mathrm{pH} \leq 1.0$ followed by keeping of the reaction mixture at room temperature to achieve complete evaporation of water. Yield $15.31 \mathrm{~g}(\sim 100 \%)$, white crystals, mp. $145-147^{\circ} \mathrm{C}$. IR spectrum, $v, \mathrm{~cm}^{-1}: 3215,3020(\mathrm{NH}) ; 2942,2898$ $(\mathrm{NH}, \mathrm{CH}) ; 2706,2686,2542\left(\left[\mathrm{NH}_{2}\right]^{+}\right) ; 1570,1510$ $\left[\delta\left(\mathrm{N}^{+} \mathrm{H}_{2}\right)\right] ; 1262,1225,1207\left(\mathrm{SO}_{2}\right) ; 1059,1029\left(\mathrm{SO}_{2}\right)$; 547, $532(\mathrm{~S}-\mathrm{O})$. Mass spectrum FAB: $\left[\mathrm{M}-\mathrm{NH}_{3}+2 \mathrm{H}\right]^{+}$ $(\mathrm{m} / \mathrm{z} 138, \mathrm{I}, 10 \%),\left[\mathrm{M}-\mathrm{NH}_{3}+\mathrm{H}\right]^{+}(\mathrm{m} / \mathrm{z}$ 137, I, 33\%), $\left[\mathrm{M}-\mathrm{NH}_{3}\right]^{+}(\mathrm{m} / \mathrm{z} 136, \mathrm{I}, 39 \%)$. Anal. calcd. $\mathrm{C}_{4} \mathrm{H}_{11} \mathrm{NO}_{3} \mathrm{~S}$ : C 31.36; H 7.24; $\mathrm{N}$ 9.14; $\mathrm{S} 20.93$. Found: C 31.94; H 7.12; N 8.91; S 20.47. M 153.20.

$N$-(tert-Butyl)aminomethanesulfonic acid (IVa) was prepared using the procedure similar to that described elsewhere [9]. Mass spectrum EI: m/z 91, I, $10 \%$; $\left[\mathrm{M}-\mathrm{SO}_{3}-2 \mathrm{H}\right]^{+}(\mathrm{m} / \mathrm{z} 85, \mathrm{I}, 13 \%)$; [M- $\mathrm{SO}_{3}-$

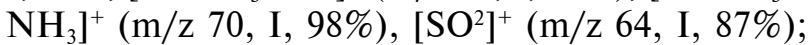
$\left[\left(\mathrm{CH}_{3}\right)_{3} \mathrm{C}\right]^{+}(\mathrm{m} / \mathrm{z} 57, \mathrm{I}, 100 \%) ;[\mathrm{SO}]^{+}(\mathrm{m} / \mathrm{z} 48, \mathrm{I}$, $38 \%)$.
The aqueous solutions of sodium salts $\mathrm{Ib}-\mathrm{IVb}$ were prepared by reacting $\mathrm{NaOH}$ with the corresponding Ia-IVa acids in equimolar amounts.

\section{Characterization}

IR spectra were recorded using a Spectrum BX II FTIR System (Perkin-Elmer) spectrophotometer in the range of $4000-350 \mathrm{~cm}^{-1}$ from $\mathrm{KBr}$ pellets. Mass spectra were registered by a MX-1321 instrument (direct input of the sample into the ion source, energy of ionizing electrons $70 \mathrm{eV}$ ). IR spectroscopy data of the compounds $2 \mathrm{a}$ and $3 \mathrm{a}$ indicated that the zwitter-ionic structures similar to the earlier investigated analogs $[6,8,9]$.

The FAB mass spectra were registered by means of a spectrometer VG 7070 (VG Analytical) (desorption of ions from the surface of a liquid phase was performed by a beam of argon atoms with energy of $8 \mathrm{keV}, \mathrm{m}$-nitrobenzyl alcohol was used as a matrix).

Elemental analysis of carbon, hydrogen, and nitrogen was done using a $\mathrm{CNH}$ analyzer; sulfur content was determined in Schoeniger flask. The values of index of $\lg \mathrm{P}_{\text {ow }}$ were calculated by QSAR method with HyperChem 8.01 program.

$\mathrm{X}$-ray study was carried out with the automated Oxford Diffraction diffractometer $\left(\mathrm{MoK}_{\alpha}\right.$-radiation, graphite monochromator, the Sapphire-3 CCD-detector). The structure was solved with the SHELX-97 and WinGX program packages [10]. Hydrogen atoms were found from the Fourier D-map and refined using the riding model for the methyl and methylene $\mathrm{H}$-atoms. The hydrogen atoms involved into hydrogen bonds were refined isotropically. The main crystal data and refinement results for the 3a crystal are presented in Table 1. Full data on the structure 3 a have been deposited at the Cambridge Crystallographic Data Centre under the number CCDC 1818345 and can be obtained on application to CCDC, 12 Union Road, Cambridge CB2 IEZ, UK (fax: +44-1223-336-033; E-mail: deposit@ ccdc.cam.ac.uk or http://www.ccdc.cam.ac.uk).

Powder diffraction study was carried out using a Siemens D500 diffractometer (Bragg-Brentano geometry, $\mathrm{CuK}_{\alpha}$ radiation, diffracted-beam graphite monochromator).

\section{Biological assays}

The toxicity of AMSA derivatives was studied on 132 male mice (ISR line with $18-25 \mathrm{~g}$ weight) that were bred in experimental biologic clinics of Odessa National Medical University. The animals were kept on a common food diet with free access to food and water. Animal studies were carried out in compliance with the provisions of the European Convention for the Protection of Animals used for Experimental and Other Scientific Purposes

R.E. Khoma, V.N. Baumer, P.B. Antonenko, A.O. Snihach, V.V. Godovan, A.A. Ennan, R.M. Dlubovskii, V.O. Gelmboldt 
Table 1

Selected crystallographic data and structure refinement parameters of $\mathrm{n}-\mathrm{C}_{3} \mathrm{H}_{7} \mathrm{~N}_{2} \mathrm{CH}_{2} \mathrm{SO}_{3}^{-}$(IIIa)

\begin{tabular}{l|c}
\hline Empirical formula & $\mathrm{C}_{4} \mathrm{H}_{13} \mathrm{NO}_{3} \mathrm{~S}$ \\
\hline Formula mass & 153.20 \\
\hline Temperature, $\mathrm{T}(\mathrm{K})$ & $293(2) \mathrm{K}$ \\
\hline Crystal system & Orthorhombic \\
\hline Space group & $\mathrm{Iba} 2$ \\
\hline $\mathrm{a}(\AA)$ & $8.8405(6)$ \\
\hline $\mathrm{b}(\AA)$ & $20.6348(12)$ \\
\hline $\mathrm{c}(\AA)$ & $8.0433(7)$ \\
\hline Unit-cell volume, $\mathrm{V}\left(\AA^{3}\right)$ & $1467.27(18)$ \\
\hline Formula per unit cell, $Z$ & 8 \\
\hline Density, Dcalcd $\left(\mathrm{g} \mathrm{cm}{ }^{-3}\right)$ & 1,387 \\
\hline Crystal size $(\mathrm{mm})$ & $0.10 \times 0.15 \times 0.34$ \\
\hline Absorption coefficient, & 0.346 \\
$\left.\mu \mu(\mathrm{mm})^{-1}\right)$ & $3.75-25.98$ \\
\hline$\theta$ range $\left({ }^{0}\right)$ & $0.8740 / 0.9931$ \\
\hline$T_{\min } / T_{\max }$ & 94.3 \\
\hline Fullness, $\%$ & 4828 \\
\hline No. of reflections & 1257 \\
\hline No. of unique reflections & $\mathrm{R} 1=0.0347, \mathrm{wR}^{2}=0.0865$ \\
\hline $\mathrm{R}$ indices $[\mathrm{I}>2 \sigma(\mathrm{I})]$ & $\mathrm{R} 1=0.0409, \mathrm{wR}^{2}=0.0940$ \\
\hline $\mathrm{R}$ indices $($ all data) & 0.982 \\
\hline $\mathrm{S}$ & $-0.160 / 0.189$ \\
\hline$\Delta \rho_{\min } / \rho_{\max }, \mathrm{e} / \AA^{3}$ &
\end{tabular}

(Strasbourg, 1986, with changes made in 1998) and Basel declaration defending animal research (2010). The tested substances included the following, four derivatives of AMSA (as sodium salt): aminomethanesulfonic acid (Ib), N-(tert-butyl)aminomethanesulfonic acid (IVb), N-methylaminomethanesulfonic acid (IIb), N-(n-propyl)aminomethanesulfonic acid (IIIb).

At the preliminary stage, the boundaries of new compounds toxicity has been studied $(n=3)$ [11]. During the next stage, clarification of toxicity was performed within the doses established on the first stage $(n=5)$. Aqueous solutions of compounds $1 b-$ $4 \mathrm{~b}$ were injected once either intraperitoneally or orally, taking into account the volume of the solution, depending on the route of administration. The compounds were given orally by a syringe with a special attachment, which prevents oesophagus injury of the involved animals.

The leading criterion for toxicity of the studied compounds was $\mathrm{LD}_{50}$, which was determined using the probit analysis of mortality curves with the help of «StatPlus 2009» program (AnalystSoft, USA, 2009). In addition, we have calculated a few indexes of the compounds toxicity as follows: inverse value of medium toxicity (absolute toxicity), $1 / \mathrm{LD}_{50}$; range of lethal doses (toxicity zone), $\mathrm{LD}_{84} / \mathrm{LD}_{16}$; total index of toxicity, $1 /\left(\mathrm{LD}_{50}-\mathrm{S}\right)$; and function of angle slope (range of lethal doses), S. The value of $\mathrm{S}$ was determined according to the following equation:

$$
\mathrm{S}=\left(\mathrm{LD}_{84} / \mathrm{LD}_{50}+\mathrm{LD}_{50} / \mathrm{LD}_{16}\right) / 2 \text {. }
$$

\section{Results and discussion}

\section{Chemistry}

Aminomethanesulfonic acid (AMSA, Ia) was prepared using a one-step synthesis method [6] (Eq. (2)).

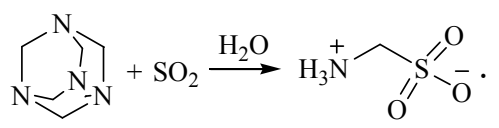

$\mathrm{N}$-alkylated AMSA derivatives were synthesized using the reaction of formaldehyde with various primary alkylamine in two stages without isolation of the intermediate product in the first stage $[8,9]$ :<smiles>[R]N1CN([R])CN([R])C1</smiles><smiles>[R]NCS(=O)(=O)[O-]</smiles>

where $\mathrm{R}=\mathrm{CH}_{3}(2 \mathrm{a}), \mathrm{CH}_{3} \mathrm{CH}_{2} \mathrm{CH}_{2}(3 \mathrm{a})$, or $\left(\mathrm{CH}_{3}\right)_{3} \mathrm{C}(4 \mathrm{a})$.

The basic zwitter-ionic n- $\mathrm{C}_{3} \mathrm{H}_{7} \stackrel{+}{\mathrm{N}} \mathrm{H}_{2} \mathrm{CH}_{2} \mathrm{SO}_{3}^{-}$unit for the structure $3 \mathrm{a}$ is shown in Fig. 1; the values of bond lengths and bond angles are listed in Table 2. The atoms $\mathrm{S}(1), \mathrm{N}(1), \mathrm{C}(1)-\mathrm{C}(4)$ are planar within $0.027 \AA$, the deviation of oxygen atoms from this plane is 1.151(4), 0.243(4), and -1.223(4) $\AA$ for $\mathrm{O}(1)$, $\mathrm{O}(2)$ and $\mathrm{O}(3)$, respectively.

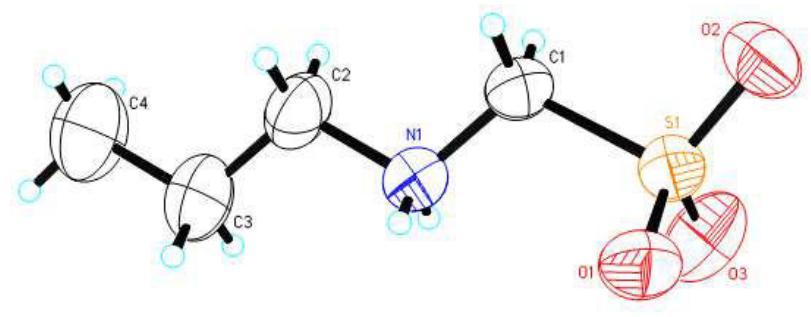

Fig. 1. Atomic numbering scheme and the thermal ellipsoids in the molecule of $\mathrm{N}$-( $n$-propyl)-aminomethanesulfonic acid (3a) (50\% probability)

Synthesis, crystal structure, and spectral characteristics of $N$-(n-propyl)aminomethanesulfonic acid. Acute toxicity of aminomethanesulfonic acid and its $\mathrm{N}$-alkylated derivatives 
When packed in a crystal (Fig. 2), the molecules form the layers in $\mathrm{z}=0$ and $\mathrm{z}=0.5$ planes in such $\mathrm{a}$ way that the polar parts of the molecules from the neighboring layers interact with the formation of hydrogen bonds. The bond $\mathrm{N}(1)-\mathrm{H}(1 \mathrm{D}) \ldots \mathrm{O}(1)^{\mathrm{x},-\mathrm{y}+1, \mathrm{z}-1 / 2}$ is a classical hydrogen bond due to which molecules in a layer are combing into pairs, while $\mathrm{N}(1)-\mathrm{H}(1 \mathrm{C}) \cdots$ $\ldots \mathrm{O}(1)^{-\mathrm{x}+1,-\mathrm{y}+1, \mathrm{z}}$ and $\mathrm{N}(1)-\mathrm{H}(1 \mathrm{C}) \cdots \mathrm{O}(3)^{\mathrm{x},-\mathrm{y}+1, \mathrm{z}+1 / 2}$ are bifurcated $\mathrm{H}$-bonds of $\mathrm{N}(1)$ atom with oxygen atoms lying in the adjacent layers. Thus, a one-dimensional system of $\mathrm{H}$-bonds along the crystallographic axis c appears in this structure (Fig. 2). The characteristics of the hydrogen bonds are given in Table 3 .

The Rietveld analysis of the X-ray powder pattern, which was performed by FullProf software
(Rodriguez-Carvajal J., Roisnel T. FullProf.98 and WinPLOTR: New Windows 95/NT Applications for Diffraction. Commission for powder diffraction, International Union of Crystallography. - Newsletter no 20. 1998 May-Aug), shows that the sample IIIa is a single phase that does not include any impurities (Fig. 3).

Hence, a possibility of the direct synthesis of $\mathrm{N}$-derivatives of aminomethanesulfonic acid through the condensation accompanied by oxidation $\mathrm{S}(\mathrm{IV}) \rightarrow \mathrm{S}(\mathrm{VI})$ was confirmed using the system $\mathrm{SO}_{2}-\mathrm{AlkNH}_{2}-\mathrm{CH}_{2} \mathrm{O}-\mathrm{H}_{2} \mathrm{O}\left(\mathrm{Alk}=\mathrm{CH}_{3}, \mathrm{CH}_{3} \mathrm{CH}_{2} \mathrm{CH}_{2}\right)$ as an example.

Biological activity

The AMSA and its derivatives are relatively

Selected bond lengths and bond angles in the structure of $\mathrm{N}$-(n-propyl)-aminomethanesulfonic acid (IIIa)

\begin{tabular}{c|c|c|c|c|c}
\hline Bond & $\mathrm{d}, \AA$ & Angle & $\omega, \mathrm{deg}$ & Angle & $\omega$, deg \\
\hline $\mathrm{S}^{1}-\mathrm{O}^{2}$ & $1.427(2)$ & $\mathrm{O}^{2}-\mathrm{S}^{1}-\mathrm{O}^{3}$ & $116.84(15)$ & $\mathrm{O}^{1}-\mathrm{S}^{1}-\mathrm{C}^{1}$ & $104.63(9)$ \\
\hline $\mathrm{S}^{1}-\mathrm{O}^{3}$ & $1.440(2)$ & $\mathrm{O}^{2}-\mathrm{S}^{1}-\mathrm{O}^{1}$ & $112.56(13)$ & $\mathrm{C}^{1}-\mathrm{N}^{1}-\mathrm{C}^{2}$ & $110.96(18)$ \\
\hline $\mathrm{S}^{1}-\mathrm{O}^{1}$ & $1.462(2)$ & $\mathrm{O}^{3}-\mathrm{S}^{1}-\mathrm{O}^{1}$ & $110.98(13)$ & $\mathrm{N}^{1}-\mathrm{C}^{1}-\mathrm{S}^{1}$ & $113.12(14)$ \\
\hline $\mathrm{S}^{1}-\mathrm{C}^{1}$ & $1.7957(16)$ & $\mathrm{O}^{2}-\mathrm{S}^{1}-\mathrm{C}^{1}$ & $104.74(11)$ & $\mathrm{N}^{1}-\mathrm{C}^{2}-\mathrm{C}^{3}$ & $112.28(19)$ \\
\hline $\mathrm{N}^{1}-\mathrm{C}^{1}$ & $1.456(3)$ & $\mathrm{O}^{3}-\mathrm{S}^{1}-\mathrm{C}^{1}$ & $105.88(11)$ & $\mathrm{C}^{2}-\mathrm{C}^{3}-\mathrm{C}^{4}$ & $113.3(3)$ \\
\hline $\mathrm{N}^{1}-\mathrm{C}^{2}$ & $1.483(2)$ & & & & \\
\hline $\mathrm{C}^{2}-\mathrm{C}^{3}$ & $1.494(4)$ & & & & \\
\hline $\mathrm{C}^{3}-\mathrm{C}^{4}$ & $1.503(4)$ & & & & \\
\hline
\end{tabular}

Characteristics of hydrogen bonds $\mathrm{D}-\mathrm{H} \cdots \mathrm{A}$ in the molecule of $\mathrm{N}$-(n-propyl)-aminomethanesulfonic acid (IIIa)

\begin{tabular}{|c|c|c|c|c|c|}
\hline \multirow{2}{*}{$\begin{array}{c}\text { Atoms involved } \\
\text { D-H } \cdots A\end{array}$} & \multicolumn{3}{|c|}{ Distance, $\AA$} & \multirow{2}{*}{$\begin{array}{c}\text { Angle DHA, } \\
\text { deg }\end{array}$} & \multirow{2}{*}{$\begin{array}{c}\text { Coordinates of } \\
\text { atom A }\end{array}$} \\
\hline & $\mathrm{d}(\mathrm{D}-\mathrm{H})$ & $\mathrm{d}(\mathrm{H} \cdots \mathrm{A})$ & $d(D \cdots A)$ & & \\
\hline $\mathrm{N}^{1}-\mathrm{H}^{1 \mathrm{C}} \ldots \mathrm{O}^{1}$ & $0.805(19)$ & $2.158(19)$ & $2.880(3)$ & $150(2)$ & $-\mathrm{x}+1,-\mathrm{y}+1, \mathrm{z}$ \\
\hline $\mathrm{N}^{1}-\mathrm{H}^{1 \mathrm{C}} \ldots \mathrm{O}^{3}$ & $0.805(19)$ & $2.52(2)$ & $3.027(3)$ & $122.7(19)$ & $\mathrm{x},-\mathrm{y}+1, \mathrm{z}+1 / 2$ \\
\hline $\mathrm{N}^{1}-\mathrm{H}^{1 \mathrm{D}} \ldots \mathrm{O}^{1}$ & $0.801(19)$ & $2.02(2)$ & 2.794(3) & $163(3)$ & $\mathrm{x},-\mathrm{y}+1, \mathrm{z}-1 / 2$ \\
\hline
\end{tabular}

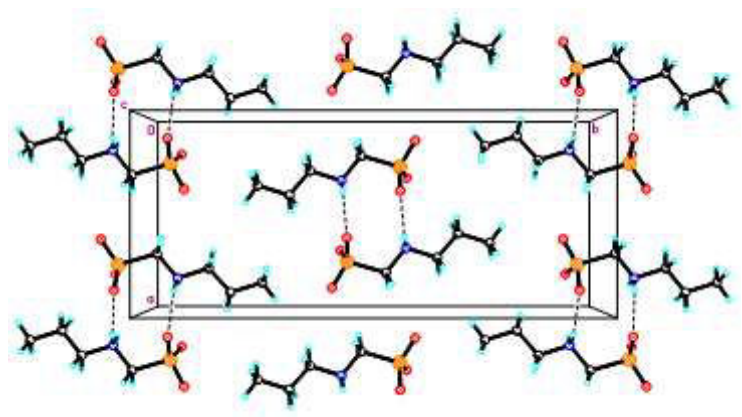

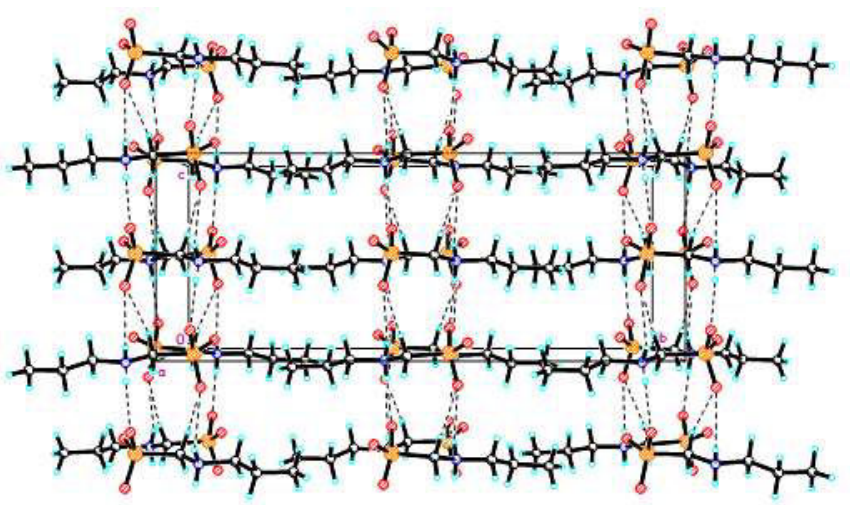

b

Fig. 2. Crystal packing and hydrogen bonds in the molecule of $\mathrm{N}$-( $n$-propyl)aminomethanesulfonic acid (IIIa): a - the location of the molecules in a layer; and b - the mutual arrangement of layers and hydrogen bonds system. Hydrogen bonds are depicted by dashed lines

R.E. Khoma, V.N. Baumer, P.B. Antonenko, A.O. Snihach, V.V. Godovan, A.A. Ennan, R.M. Dlubovskii, V.O. Gelmboldt 


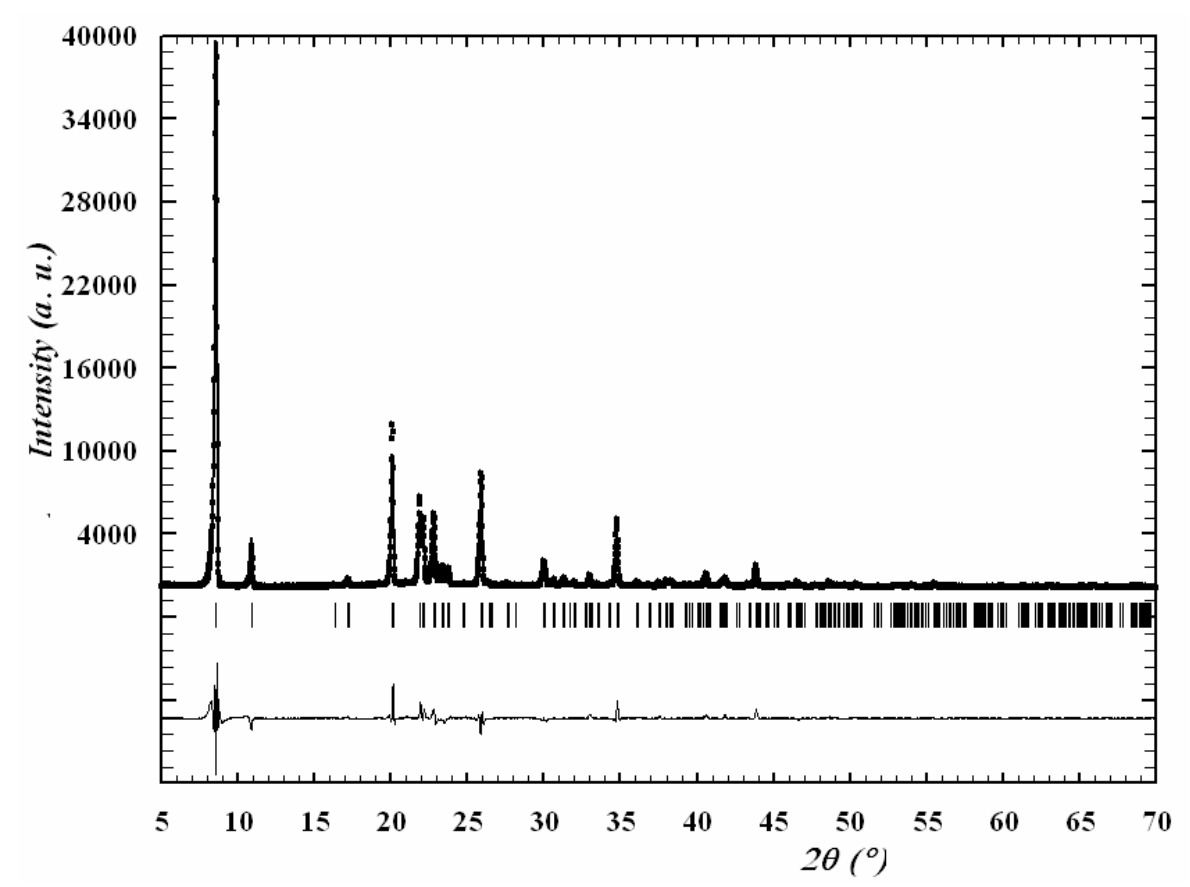

Fig. 3. The Rietveld refinement results for the powder diffraction pattern of the sample 3a. The observed intensities are represented by circles and calculated ones are shown as a solid line. Vertical bars show the Bragg position of the diffraction maxima. The bottom curve shows the difference between the observed and calculated intensity at each point

slightly soluble, so the sodium salts of acids were used for toxicity assay. At the preliminary stage, the upper ( $100 \%$ lethal outcome) and lower limits $(0 \%$ lethal outcome) of $\mathrm{LD}_{50}$ were determined (Table 4).

Table 4

Range of toxic doses of aminomethanesulfonic acid derivatives at the preliminary stage of study $(\mathrm{mg} / \mathrm{kg})$

\begin{tabular}{c|c|c}
\hline \multirow{2}{*}{ Compound } & \multicolumn{2}{|c}{ Route of administration } \\
\cline { 2 - 3 } & Oral & Intraperitoneal \\
\hline $\mathrm{Ib}$ & $>5000$ & $3000 \div 5000$ \\
\hline $\mathrm{IIb}$ & $>5000$ & $1000 \div 5000$ \\
\hline $\mathrm{IIIb}$ & $>5000$ & $1000 \div 3000$ \\
\hline $\mathrm{IVb}$ & $>5000$ & $3000 \div 5000$ \\
\hline
\end{tabular}

Changes in the behavior of experimental animals after oral administration of new compounds at the highest dose of $5000 \mathrm{mg} / \mathrm{kg}$ were similar for all the studied AMSA derivatives. For instance, just after the substances administration, there was a decrease in motor activity, general sedation, and extension of the posterior extremities. However, on the next day, the behavior of exposed animals did not differ from those of control animals. An intraperitoneal administration of new compounds in lethal doses led to an increased restlessness of animals followed by a decreased motor activity and sluggishness, and finally to a lethal outcome.

The purpose of the next stage was to determine the values of toxicity of the new compounds via different routes of administration. According to the obtained results, oral administration of the compounds $\mathrm{Ib}-\mathrm{IVb}$ did not cause death of experimental animals in the range of $100-5000 \mathrm{mg} / \mathrm{kg}$ (Table 5). The intraperitoneal $\mathrm{LD}_{50}$ values of the same compounds were within the range of 2110$3471 \mathrm{mg} / \mathrm{kg}$. Thus, the studied AMSA derivatives represents $\mathrm{V}$ category of toxicity according to OECD guideline for testing of chemicals [12] or IV category of toxicity according to US Environmental Protection Agency [13] (Table 5). The $\mathrm{LD}_{50}$ of the compounds followed the order IIIb $<\mathrm{IIb}<\mathrm{IVb}<\mathrm{Ib}$. So, AMSA derivatives belong to the practically non-toxic compound. The fact of lower toxicity of new compounds after oral administration comparatively to intraperitoneal route witnessed certain peculiarities of their pharmacokinetics.

Presumably, after the administration of aqueous solutions of sodium aminomethanesulfonates, an increase in the $\mathrm{pH}$ of the physiological fluid occurs due to the following processes:

$\mathrm{RNHCH}_{2} \mathrm{SO}_{3} \mathrm{Na} \rightarrow \mathrm{RNHCH}_{2} \mathrm{SO}_{3}^{-}+\mathrm{Na}^{+}$;

$\mathrm{RNHCH}_{2} \mathrm{SO}_{3}^{-}+\mathrm{H}_{2} \mathrm{O} \rightleftarrows$

$\rightleftarrows \mathrm{R}^{\mathrm{N}} \mathrm{H}_{2} \mathrm{CH}_{2} \mathrm{SO}_{3}^{-}+\mathrm{OH}^{-}$;

Synthesis, crystal structure, and spectral characteristics of $N$-(n-propyl)aminomethanesulfonic acid. Acute toxicity of aminomethanesulfonic acid and its $N$-alkylated derivatives 
Toxicity of sodium aminomethanesulfonates in mice at intraperitoneal administration $(\mathrm{mg} / \mathrm{kg})$

\begin{tabular}{l|c|c|c|c}
\hline \multirow{2}{*}{ Indexes } & \multicolumn{4}{c}{ Compound } \\
\cline { 2 - 5 } & $\mathrm{Ib}$ & $\mathrm{IIb}$ & $\mathrm{IIIb}$ & $\mathrm{IVb}$ \\
\hline $\mathrm{pK}_{\mathrm{a}}[2]$ & 5.75 & 9.67 & 9.81 & 9.96 \\
\hline $\mathrm{lgP}$ & -0.67 & -0.27 & 0.55 & 0.57 \\
\hline $\mathrm{LD}_{50}$ & 3470 & 2925 & 2110 & 3020 \\
\hline $\mathrm{LD}_{10}$ & 1420 & 1130 & 420 & 1225 \\
\hline $\mathrm{LD}_{16}$ & 1875 & 1525 & 790 & 1620 \\
\hline $\mathrm{LD}_{84}$ & 5070 & 4325 & 3430 & 4415 \\
\hline $\mathrm{LD}_{90}$ & 5520 & 4720 & 3805 & 4810 \\
\hline $\mathrm{LD} D_{100}$ & 5870 & 5025 & 4090 & 5115 \\
\hline Absolute toxicity $\left(1 / \mathrm{LD}_{50}\right)$ & 0.000288 & 0.000342 & 0.000474 & 0.000331 \\
\hline Toxicity zone $\left(\mathrm{LD}_{84} / \mathrm{LD}_{16}\right)$ & 2.70 & 2.84 & 4.34 & 2.73 \\
\hline Function of angle slope $($ range of lethal doses, S) & 1.66 & 1.70 & 2.15 & 1.66 \\
\hline Total index of toxicity & 0.000288 & 0.000342 & 0.000474 & 0.000332 \\
\hline
\end{tabular}

Under the condition of oral administration, the excess of $\mathrm{OH}^{-}$is neutralized by $\mathrm{H}^{+}$ions of gastric juice, due to which the acid-base balance is stabilized. Typically, intracellular $\mathrm{pH}$ is about 7.2 and extracellular (or arterial) $\mathrm{pH}$ is between 7.36 and 7.44 [14]. After intraperitoneal administration, the $\mathrm{pH}$ excess of $\mathrm{OH}^{-}$ions causes acid-base imbalance (alkalosis) and results in metabolic disorders [14].

Comparison of toxicity values of the new compounds following intraperitoneal administration also showed some differences between them. For example, the toxicity zone for mice in compounds $\mathrm{Ib}$, IIb and IVb was in the interval of $2.70-2.84$ that is in 1.6 times lower than in compound IIIb. The above-mentioned difference between compounds is most likely related to the chemical structure of the aminomethanesulfonic acid radical.

Taking into account the range of lethal doses, that at intraperitoneal administration was $1.66-1.70$ (Ib, IIb and IVb) and 2.15 (IIIb), one can conclude that the new AMSA derivatives, especially compounds $\mathrm{Ib}$, IIb and $\mathrm{IVb}$, belong to substances without significant potential hazard or danger of poisoning. It is worth mentioning that compound IIIb, which carries the $\mathrm{N}$-( $n$-propyl) radical in its molecule, had the biggest range of lethal doses. The intermediate level of total index of toxicity was detected in compounds with N-methyl and N-(tertbutyl) radicals (IIb and IVb, respectively), while the compound without any additional radicals in its molecule (Ib) had the smallest range of lethal doses.

\section{Conclusions}

The AMSA, and its N-methyl, N-n-propyl and $\mathrm{N}$-tert-butyl derivatives were synthesized (IIIa was not previously described). The structural characterization of the obtained compounds was performed using X-ray diffraction analysis, IR spectroscopy, mass spectrometry and elemental analysis. A possibility of the direct synthesis of AMSA $\mathrm{N}$-derivatives through the condensation accompanied by oxidation $\mathrm{S}(\mathrm{IV}) \rightarrow \mathrm{S}(\mathrm{VI})$ was confirmed using the system $\mathrm{SO}_{2}-\mathrm{AlkNH}_{2}-\mathrm{CH}_{2} \mathrm{O}-\mathrm{H}_{2} \mathrm{O}$ (Alk=methyl, n-propyl) as an example. Aminomethanesulfonic acid derivatives belong to almost non-toxic compounds (V category of toxicity) following both intraperitoneal and oral administrations in mice. Moreover, oral administration of up to $5000 \mathrm{mg} / \mathrm{kg}$ of compounds did not lead to death at all. According to the $\mathrm{LD}_{50}$ values, compounds could be ranked in the following order: sodium $\mathrm{N}$-( $n$-propyl)aminomethanesulfonate $(2110 \mathrm{mg} / \mathrm{kg})<$ sodium $\mathrm{N}$-methylaminomethanesulfonate $(2925 \mathrm{mg} / \mathrm{kg})<$ sodium $\mathrm{N}$-(tert-butyl)aminomethanesulfonate $(3020 \mathrm{mg} / \mathrm{kg})<$ sodium aminomethanesulfonate $(3470 \mathrm{mg} / \mathrm{kg})$. Thus, sodium $\mathrm{N}$-(n-propyl)aminomethanesulfonate was the most toxic, while sodium salt of aminomethanesulfonic acid was the safest of all the studied substances. Aminomethanesulfonic acid derivatives may be safely used in buffer solutions as well as for further investigation as potential medicine agents.

\section{REFERENCES}

1. Grygorenko O.O., Biitseva A.V., Zhersh S. Amino sulfonic acids, peptidosulfonamides and other related compounds // Tetrahedron. - 2018. - Vol.74. - No. 13. - P.1355-1421.

2. Khoma R.E. Thermodynamics of the dissociation of aminomethanesulfonic acid and its $\mathrm{N}$-substituted derivatives in aqueous solutions at 293-313 K // Russ. J. Phys. Chem. A. 2017. - Vol.91. - No. 1. - P.76-79.

3. Synthesis, antioxidant and anti-influenza activity of

R.E. Khoma, V.N. Baumer, P.B. Antonenko, A.O. Snihach, V.V. Godovan, A.A. Ennan, R.M. Dlubovskii, V.O. Gelmboldt 
aminomethanesulphonic acids / Khoma R.E., Gelmboldt V.O., Ennan A.A., Gridina T.L., Fedchuk A.S., Lozitskiy V.P., Rakipov I.M., Vladika A.S. // Pharm. Chem. J. - 2019. - Vol.53. - No. 5. - P.436-439.

4. Investigations of the antimicrobial activity of aminomethanesulfonic acids against strains of Staphylococcus aureus with different antimicrobial susceptibility / Hrydina T.L., Khoma R.E., Ennan A.A.-A., Fedchuk A.S., Hruzevskyi O.A. // Zaporozhye Med. J. - 2019. - Vol.21. - No. 2. - P.234-239.

5. Tochitani $S$. Functions of maternally-derived taurine in fetal and neonatal brain development. // Adv. Exp. Med. Biol. 2017. - Vol.975. - P.17-25.

6. Features of interaction in the sulfur(IV) oxidehexamethylenetetramine-water system: a first example of identification of the product with a sulfur-carbon bond / Khoma R.E., Shestaka A.A., Shishkin O.V., Baumer V.N., Brusilovskii Yu.E., Koroeva L.V., Ennan A.A., Gel'mbol'dt V.O. // Russ. J. Gen. Chem. - 2011. - Vol.81. - No. 3. - P.620-621.

7. Cameron T.S., Chute W.J., Knop O. Aminosulfonic acids. Part 1. Crystal structures of N-methylaminomethanesulfonic acid, $\mathrm{MeNHCH}_{2} \mathrm{SO}_{3} \mathrm{H}$, and disodium N-methyliminobis(methanesulfonate) dihydrate, $\mathrm{MeN}\left(\mathrm{CH}_{2} \mathrm{SO}_{3} \mathrm{Na}\right)_{2} \cdot 2 \mathrm{H}_{2} \mathrm{O} / /$ Can. J. Chem. - 1984. - Vol.62. - No. 3. - P.540-548.

8. Synthesis, crystal structure, and spectral characteristics of N-(Hydroxyethyl)aminomethanesulfonic acid / Khoma R.E., Gel'mbol'dt V.O., Shishkin O.V., Baumer V.N., Koroeva L.V. // Russ. J. Gen. Chem. - 2013. - Vol.83. - No. 5. - P.969-971.

9. Synthesis, crystal structure, and spectral characteristics of N-(tert-butyl)aminomethanesulfonic acid. / Khoma R.E., Gel'mbol'dt V.O., Ennan A.A., Baumer V.N., Puzan A.N. // Russ. J. Gen. Chem. - 2015. - Vol.85. - No. 10. - P.22822284.

10. Sheldrick G.M. A short history of SHELX // Acta Crystallogr., Sect. A: Found. Crystallogr. - 2008. - Vol.64. No. 1. - P.112-122.

11. Walum E. Acute oral toxicity // Environ. Health Perspect. - 1998. - Vol.106. - P.497-503.

12. Stephanova A.V. Doklinicheskie isledovaniya lekarstvennykh sredstv. - Kyiv: Avitsena, 2002. - 567 p.

13. Prozorovskij V.B. Ispol'zovanie metoda naimen'shikh kvadratov dl'ya probit-analiza krivykh letal'nosti // Farmakologiya i Toksikologiya. - 1962. - Vol.25. - No. 1. - P.115-119.

14. Atkinson K.F. Nauli S.M. pH sensors and ion transporters: potential therapeutic targets for acid-base disorders // Int. J. Pharm. Res. Rev. - 2016. - Vol.5. - No. 3. - P.51-58.

Received 10.07.2019

Synthesis, crystal structure, and spectral characteristics of $N$-(n-propyl)aminomethanesulfonic acid. Acute toxicity of aminomethanesulfonic acid and its $N$-alkylated derivatives
СИНТЕЗ, КРИСТАЛІЧНА СТРУКТУРА І СПЕКТРАЛЬНІ ХАРАКТЕРИСТИКИ N-( $N$-ПРОПІЛ)АМІНОМЕТАНСУЛЬФОНОВОЇ КИСЛОТИ. ГОСТРА ТОКСИЧНІСТЬ АМІНОМЕТАНСУЛЬФОНОВОЇ КИСЛОТИ ТА ІІЇ N-АЛКІЛОВАНИХ ПОХІДНИХ

Р.С. Хома, В.М. Баумер, П.Б. Антоненко, А.О. Снігач, В.В. Годован, А.А. Еннан, Р.М. Длубовський, В.О. Гельмбольдт

Синтезовано амінометансульфонову кислоту (Ia) та їі $N$-метил (IIa), $N$-n-пропіл (IIIa) та $N$-трет-бутил (IVa) похідні (IIIа раніше не описано), які охарактеризовано за допомогою методів РСА, IЧ-спектроскопії та мас-спектрометрії. Амінометансульфонова кислота ІІІа цвиттеріонної структури кристалізується в орторомбічній просторовій групі $\mathrm{Iba} 23$ наступними параметрами комірки: $\mathrm{a}=8,8405$ (6) $A, \mathrm{~b}=20,6348(12) \AA$, $\mathrm{c}=8,0433(7) \AA, \alpha=\beta=\gamma=90^{\circ}, V=1467,27(18) A^{3}$. Водні розчини натрієвих солей $(\mathrm{Ib}-\mathrm{IVb})$ готували шляхом взаємодії $\mathrm{NaOH} з$ відповідними Ia-IVa кислотами в еквімолярних кількостях. Токсичність Ib-IVb вивчена на 132 мишах. Амінометансульфонати натрію відносяться до практично нетоксичних сполук (Vклас токсичності) після внутрішньочеревного та перорального введення у мишей. Відповідно до значень $L D_{50}$, солі можна розташувати в наступний ряд: $n-\mathrm{C}_{3} \mathrm{H}_{7} \mathrm{NHCH}_{2} \mathrm{SO}_{3} \mathrm{Na}(2110 \mathrm{~m} / \mathrm{\kappa r})<$ $<\mathrm{CH}_{3} \mathrm{NHCH}_{2} \mathrm{SO}_{3} \mathrm{Na}(2920 \mathrm{Mz} / \mathrm{\kappa} 2)<t-\mathrm{C}_{4} \mathrm{H}_{9} \mathrm{NHCH}_{2} \mathrm{SO}_{3} \mathrm{Na}(3020 \mathrm{~m} 2 / \mathrm{\kappa r})<$ $<\mathrm{NH}_{2} \mathrm{CH}_{2} \mathrm{SO}_{3} \mathrm{Na}(3470 \mathrm{m2} / \kappa 2)$. $\mathrm{N}$-алкіловані похідні амінометансульфонової кислоти можна безпечно використовувати як компоненти буферних розчинів, а також для подальшого дослідження як потенційні лікарські засоби.

Ключові слова: амінометансульфонові кислоти; синтез; кристалічна структура; спектральні характеристики; гостра токсичність.

\section{SYNTHESIS, CRYSTAL STRUCTURE, AND SPECTRAL CHARACTERISTICS OF N-(N- PROPYL)AMINOMETHANESULFONIC ACID. ACUTE TOXICITY OF AMINOMETHANESULFONIC ACID AND ITS N-ALKYLATED DERIVATIVES \\ R.E. Khoma ${ }^{a, b}$, *, V.N. Baumer ${ }^{c}$, P.B. Antonenko ${ }^{d}$, A.O. Snihach ", V.V. Godovan ", A.A. Ennan ${ }^{a}$, R.M. Dlubovskii ${ }^{a}$, V.V. Gelmboldt ${ }^{d}$}

a Physical-Chemical Institute for Environment and Human Protection of MES of Ukraine and NAS of Ukraine, Odessa, Ukraine

b Odessa I.I. Mechnikov National University, Odessa, Ukraine c Institute for Single Crystals of the National Academy of Sciences of Ukraine, Kharkiv, Ukraine

d Odessa National Medical University, Odessa, Ukraine *e-mail: rek@onu.edu.ua

Aminomethanesulfonic acid (Ia), and its N-methyl (IIa), $N$ n-propyl (IIIa), $N$-tert-butyl (IVa) derivatives were synthesized (IIIa has not been previously described) and characterized by means of $X$-ray diffraction analysis, IR spectroscopy, and mass spectrometry. Aminosulfonic acid $3 a$ of zwitterionic structure crystallizes in the orthorhombic space group Iba2 with the following cell parameters: $a=8.8405(6) \AA, b=20.6348(12) \AA, c=8.0433(7) \AA, \alpha=\beta=\gamma=90^{\circ}$, $V=1467.27(18) A^{3}$. The aqueous solutions of sodium salts $(I b-I V b)$ were prepared by reacting $\mathrm{NaOH}$ with the corresponding Ia-IVa acids in equimolar amounts. The toxicity of $I b-I V b$ was studied on 132 mice. The derivatives of aminomethanesulfonic acid belong to almost non-toxic compounds ( $V$ category of toxicity) following both intraperitoneal and oral administration in mice. According to the 
$L D_{50}$ values, the compounds could be ranked in the following order: IIIb $(2110 \mathrm{mg} / \mathrm{kg})<I I b(2925 \mathrm{mg} / \mathrm{kg})<I V b(3020 \mathrm{mg} / \mathrm{kg})<\mathrm{Ib}$ $(3470 \mathrm{mg} / \mathrm{kg})$. Aminomethanesulfonic acid derivatives may be safely used in buffer solution as well as for further investigation as potential medicine agents.

Keywords: aminomethanesulfonic acids; synthesis; crystal structure; spectral characteristics; acute toxicity.

\section{REFERENCES}

1. Grygorenko O.O., Biitseva A.V., Zhersh S. Amino sulfonic acids, peptidosulfonamides and other related compounds. Tetrahedron, 2018, vol. 74, pp. 1355-1421.

2. Khoma R.E. Thermodynamics of the dissociation of aminomethanesulfonic acid and its $\mathrm{N}$-substituted derivatives in aqueous solutions at 293-313 K. Russian Journal of Physical Chemistry A, 2017, vol. 91, pp. 76-79.

3. Khoma R.E., Gelmboldt V.O., Ennan A.A., Gridina T.L., Fedchuk A.S., Lozitskiy V.P., Rakipov I.M., Vladika A.S. Synthesis, antioxidant and anti-influenza activity of aminomethanesulphonic acids. Pharmaceutical Chemistry Journal, 2019, vol. 53, pp. 436-439.

4. Hrydina T.L., Khoma R.E., Ennan A.A.-A., Fedchuk A.S., Hruzevskyi O.A. Investigations of the antimicrobial activity of aminomethanesulfonic acids against strains of Staphylococcus aureus with different antimicrobial susceptibility. Zaporozhye Medical Journal, 2019, vol. 21, no. 2, pp. 234-239. (in Ukrainian).

5. Tochitani S. Functions of maternally-derived taurine in fetal and neonatal brain development. In: Lee D.H., Schaffer S.W., Park E., Kim H.W. (eds.) Taurine 10. Advances in Experimental Medicine and Biology, 2017, vol. 975, pp. 17-25.

6. Khoma R.E., Shestaka A.A., Shishkin O.V., Baumer V.N., Brusilovskii Yu.E., Koroeva L.V., Ennan A.A., Gel'mbol'dt V.O. Features of interaction in the sulfur(IV) oxide-hexamethylenetetramine-water system: a first example of identification of the product with a sulfur-carbon bond. Russian Journal of General Chemistry, 2011, vol. 81, pp. 620-621.
7. Cameron T.S., Chute W.J., Knop O. Aminosulfonic acids. Part 1. Crystal structures of N-methylaminomethanesulfonic acid, $\mathrm{MeNHCH}_{2} \mathrm{SO}_{3} \mathrm{H}$, and disodium N-methyliminobis(methanesulfonate) dihydrate, $\mathrm{MeN}\left(\mathrm{CH}_{2} \mathrm{SO}_{3} \mathrm{Na}\right)_{2} \cdot 2 \mathrm{H}_{2} \mathrm{O}$. Canadian Journal of Chemistry, 1984, vol. 62, pp. 540-548.

8. Khoma R.E., Gel'mbol'dt V.O., Shishkin O.V., Baumer V.N., Koroeva L.V. Synthesis, crystal structure, and spectral characteristics of N-(hydroxyethyl)aminomethanesulfonic acid. Russian Journal of General Chemistry, 2013, vol. 83, pp. 969-971.

9. Khoma R.E., Gel'mbol'dt V.O., Ennan A.A., Baumer V.N., Puzan A.N. Synthesis, crystal structure, and spectral characteristics of N-(tert-butyl)aminomethanesulfonic acid. Russian Journal of General Chemistry, 2015, vol. 85, pp. 2282-2284.

10. Sheldrick G.M. A short history of SHELX. Acta Crystallographica Section A: Foundations and Advances, 2008, vol. 64, pp. 112-122.

11. Walum E. Acute oral toxicity. Environmental Health Perspectives, 1998, vol. 106, pp. 497-503.

12. Stephanova A.V., Doklinicheskie isledovaniya lekarstvenykh sredstv [Preclinical studies of medical agents]. Avitsena Publishers, Kyiv, 2002. 567 p. (in Russian).

13. Prozorovskii V.B. Ispol'zovanie metoda naimen'shikh kvadratov dl'ya probit-analiza krivykh letal'nosti [Using the method of least squares for probit analysis of mortality curves]. Farmakologiya i Toksikologiya, 1962, vol. 25, no. 1, pp. 115-119. (in Russian).

14. Atkinson K.F., Nauli S.M. pH sensors and ion transporters: potential therapeutic targets for acid-base disorders. International Journal of Pharma Research \& Review, 2016, vol. 5, pp. 51-58. 